\title{
Highly Sensitive D-A-D Type Near-Infrared Fluorescent Probe for Nitric Oxide Real-Time Imaging in Inflammatory Bowel Disease
}

Senyao Liu, Yu Zhu, Peng Wu, and $\mathrm{Hu}$ Xiong*

Research Center for Analytical Sciences, Tianjin Key Laboratory of Biosensing and Molecular Recognition, College of Chemistry, Nankai University, Tianjin 300071, China.

*Correspondence should be addressed to xionghu@nankai.edu.cn

\section{Supporting Information}

\section{Contents}

1. General information .S-2

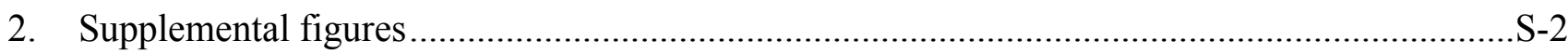

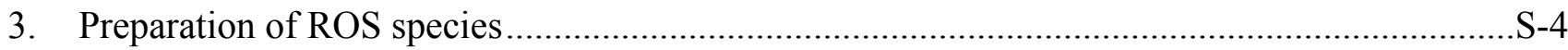

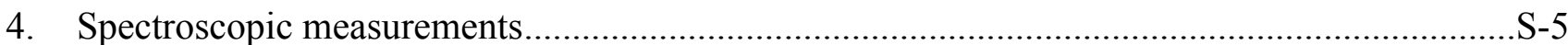

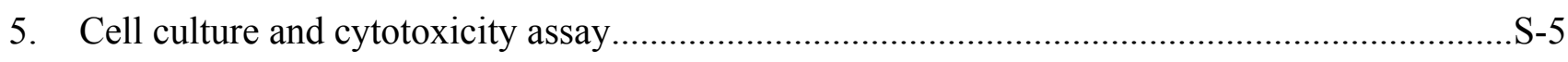

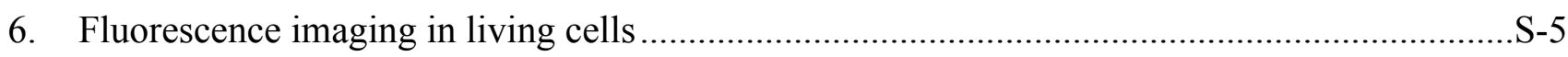

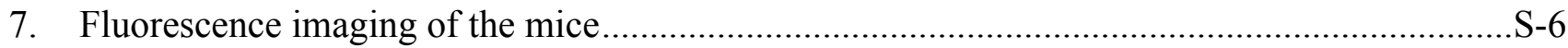

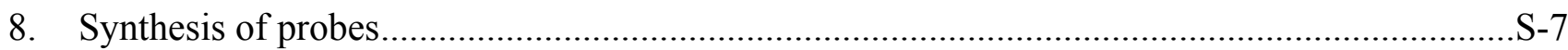

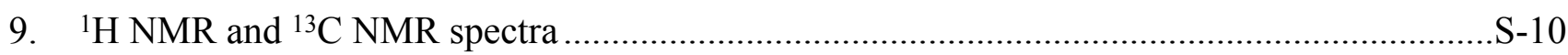

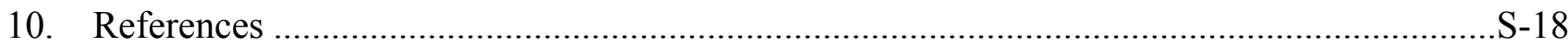




\section{General information}

All reagents and solvents were purchased from Aladdin, Bidepharm and J\&K and used without further purification. Dulbecco's Modified Eagle Medium (DMEM), RPMI-1640 Medium and fetal bovine serum (FBS) were purchased from Tianjin Kaimeihong Biological Technology Co., Ltd. LysoTracker Green and DAPI were purchased from Yingwei Jieji (Shanghai) Trading Co., Ltd. The ${ }^{1} \mathrm{H}$ NMR and ${ }^{13} \mathrm{C}$ NMR spectra were recorded on a Bruker AM $400 \mathrm{MHz}$ and $100 \mathrm{MHz}$ spectrometer in $\mathrm{CDCl}_{3}$ or DMSO-d $\mathrm{d}_{6}$, respectively. All ${ }^{1} \mathrm{H}$ NMR signals were reported in ppm with chloroform signal at $7.26 \mathrm{ppm}$ or dimethyl sulfoxide signal at $2.50 \mathrm{ppm}$ as a standard. Data for ${ }^{1} \mathrm{H}$ NMR were recorded as follows: chemical shift $(\delta, \mathrm{ppm})$, multiplicity $(\mathrm{s}=$ singlet, $\mathrm{d}=$ doublet, $\mathrm{t}=$ triplet, $\mathrm{q}=$ quartiplet, $\mathrm{m}$ $=$ multiplet or unresolved, coupling constant(s) in Hz, integration). All ${ }^{13} \mathrm{C}$ NMR signals were reported in ppm with the internal chloroform signal at $77.2 \mathrm{ppm}$ or dimethyl sulfoxide signal at $39.5 \mathrm{ppm}$ as a standard. The absorbance spectra and fluorescence spectra were obtained on the UV-vis spectrophotometer (Shimadzu, UV-2600) and Hitachi F4700 fluorometer (1 cm quartz cell), respectively. The fluorescence images of cells were acquired using a NIKON A1+ confocal and images were analyzed using Image J (NIH). The whole body and ex vivo organ fluorescence imaging was performed on an IVIS Lumina System. Cell viability was measured by CCK-8 assay on a Tecan Infinite M Plex microplate reader.

\section{Supplemental figures}
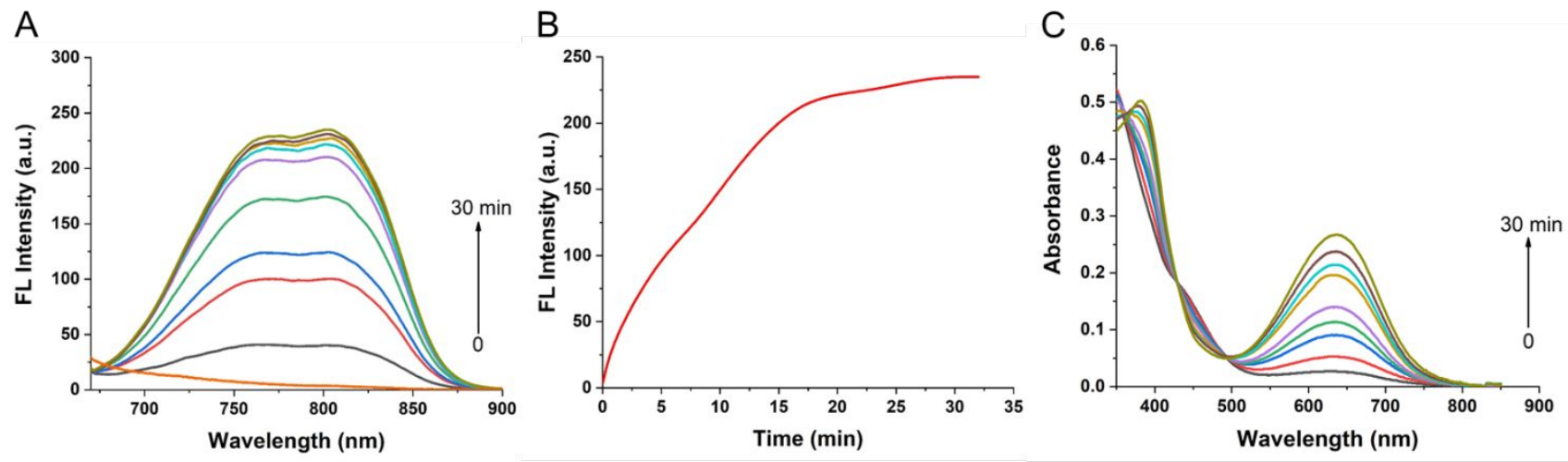

Figure S1. (A) Time-dependent fluorescence spectra of LS-NO $(30 \mu \mathrm{M})$ upon addition of $60 \mu \mathrm{M}$ NO in a mixture of $\mathrm{DMF} / \mathrm{aqueous}$ solution $(\mathrm{v} / \mathrm{v}, 1 / 1), \lambda_{\mathrm{ex}}=650 \mathrm{~nm}$. (B) Real-time records $(0-30 \mathrm{~min})$ of fluorescence intensity at $804 \mathrm{~nm}$ for the reaction of LS-NO $(30 \mu \mathrm{M})$ with $60 \mu \mathrm{M}$ NO. (C) Timedependent absorbance spectra of LS-NO $(30 \mu \mathrm{M})$ in the presence of $60 \mu \mathrm{M}$ NO. 

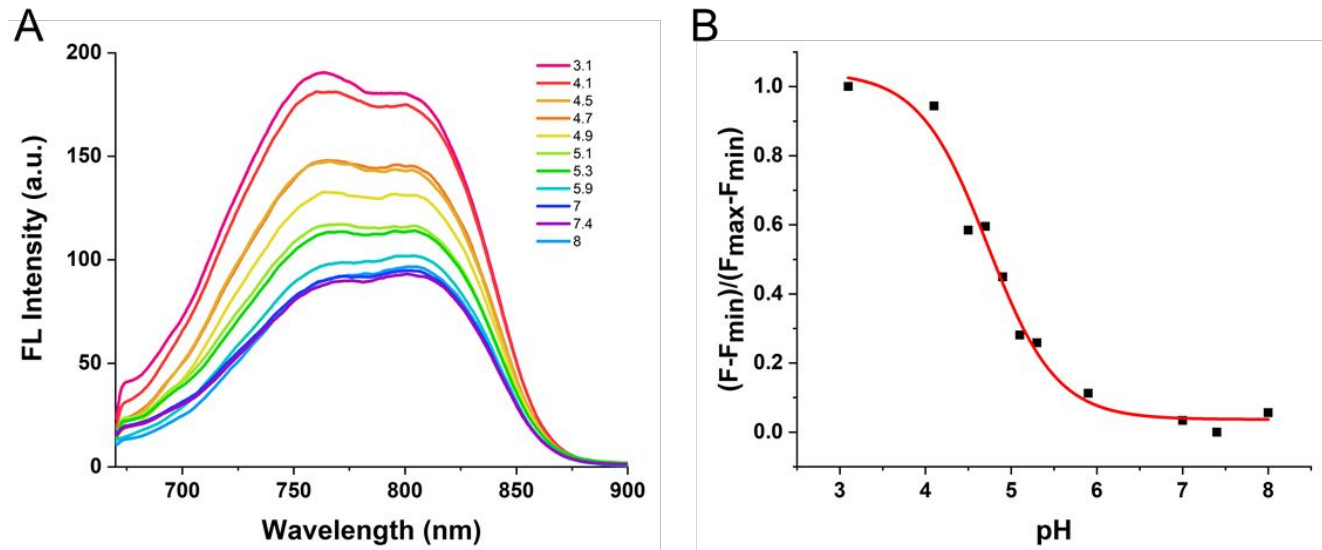

Figure S2. (A) NIR fluorescence spectra of $50 \mu \mathrm{M}$ LS-NO treated with $100 \mu \mathrm{M}$ NO in different $\mathrm{pH}$ solutions (DMF/aqueous, $\mathrm{v} / \mathrm{v}, 1 / 1), \lambda_{\mathrm{ex}}=650 \mathrm{~nm}$. (B) Normalized $\mathrm{pH}$ titration profile of the reaction between LS-NO and 2 equiv of $\mathrm{NO}(\mathrm{pKa}=4.78)$.
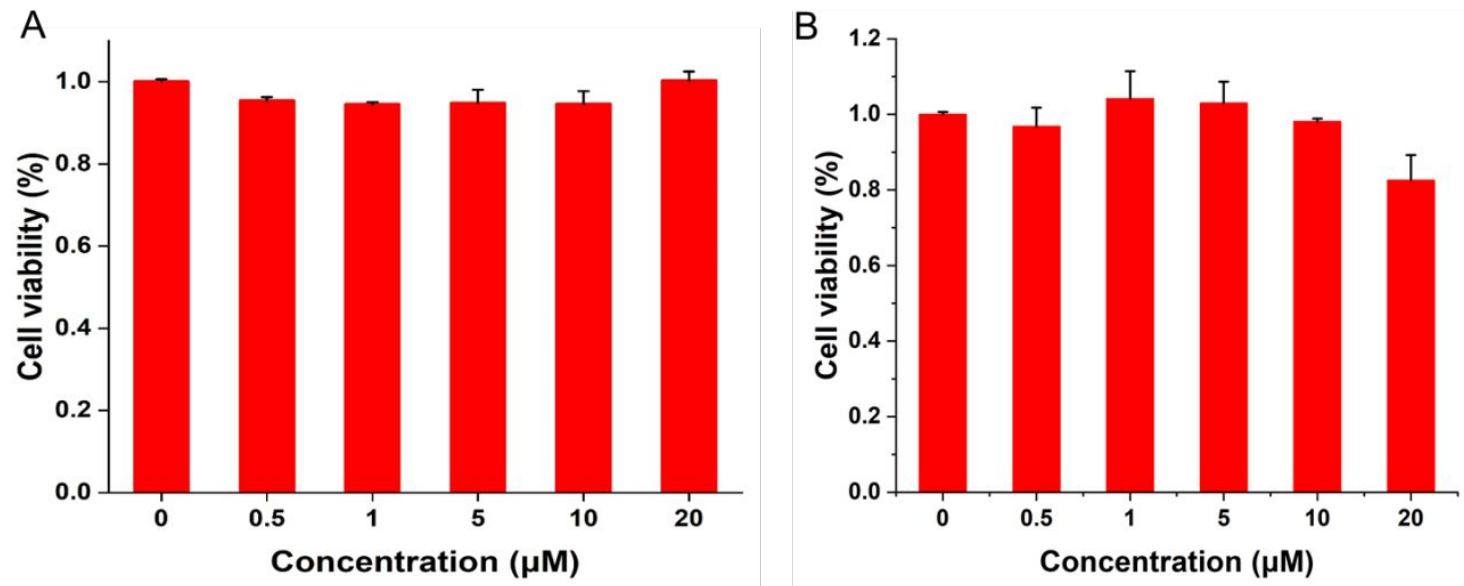

Figure S3. Cell viability of Hela cells incubated with different concentrations of LS-NO (A) and LSTZ (B) by CCK-8 assay $(n=3)$.
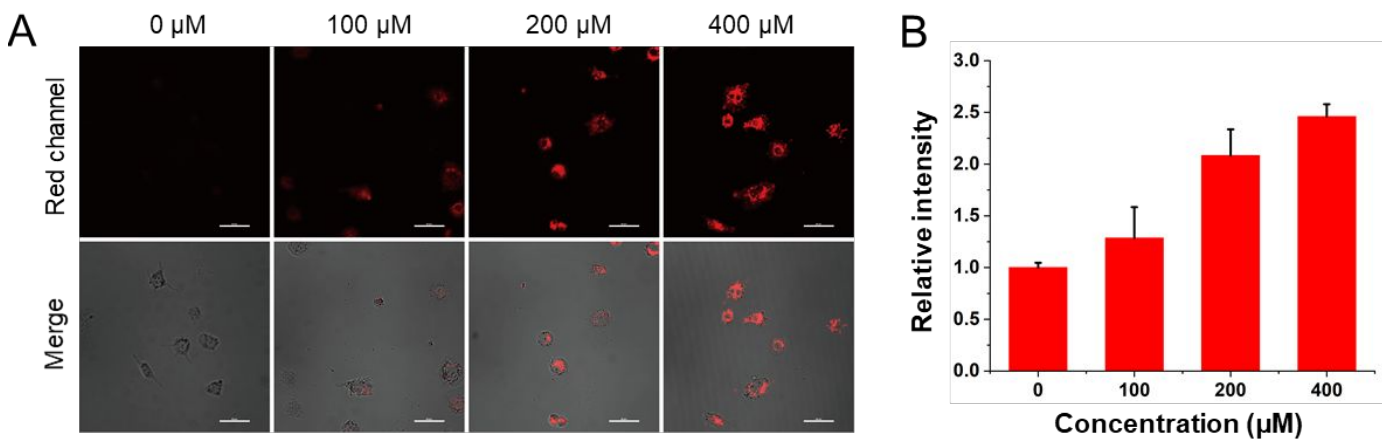

Figure S4. (A) Confocal fluorescence images of $5 \mu \mathrm{M}$ LS-NO-loaded RAW264.7 cells incubated with different SNP concentration $(0,100,200,400 \mu \mathrm{M})$ for $1 \mathrm{~h}$. (B) Relative fluorescence intensity of images in Figure S4A. 


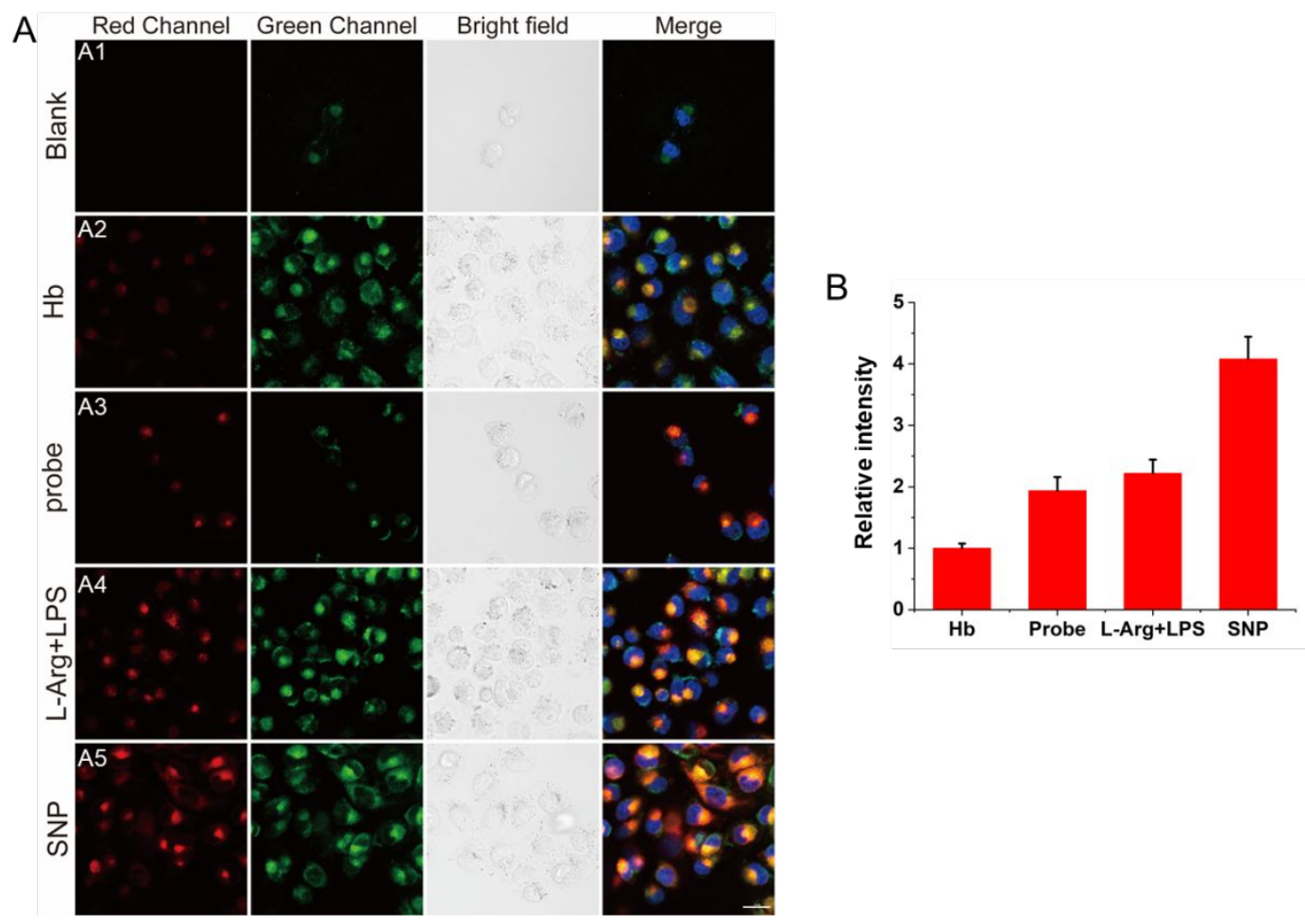

Figure S5. (A) Confocal fluorescence images of HCC1299 cells. (A1) Cells were incubated normally. (A2) Cells were pretreated with $30 \mu \mathrm{g} / \mathrm{mL}$ hemoglobin $(\mathrm{Hb})$ for $2 \mathrm{~h}$, and then incubated with $5 \mu \mathrm{M}$ LS-NO for $1 \mathrm{~h}$. (A3) Cells were incubated with $5 \mu \mathrm{M}$ LS-NO for $1 \mathrm{~h}$. (A4) Cells were pretreated with NO stimulant ( $20 \mu \mathrm{g} / \mathrm{mL}$ LPS, and $5 \mathrm{mg} / \mathrm{mL} \mathrm{L} \mathrm{-Arg)} \mathrm{for} 12 \mathrm{~h}$, and then incubated with LS-NO for 1 h. (A5) Cells were pretreated with $400 \mu \mathrm{M}$ SNP for $1 \mathrm{~h}$, and then incubated with $5 \mu \mathrm{M}$ LS-NO for 1 h. (B) Relative fluorescence intensity of images (A1-A5). $\lambda_{\text {ex }}=638 \mathrm{~nm}, \lambda_{\text {em }}=663-738 \mathrm{~nm}$. Scale bar $=25 \mu \mathrm{m}$.
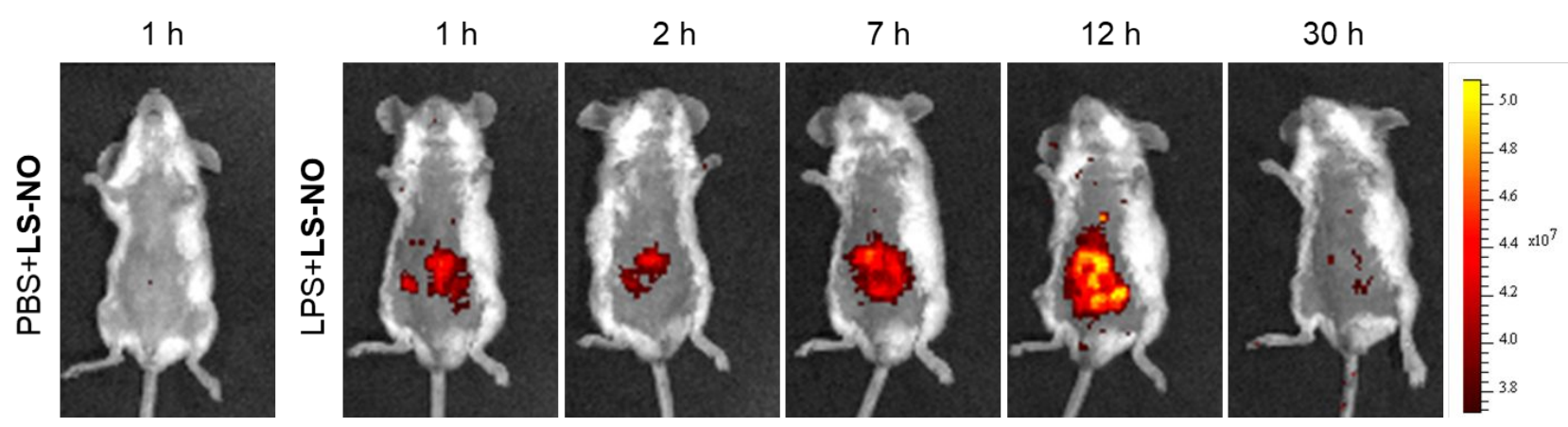

Figure S6. Time-dependent in vivo NIR fluorescence images of normal mice and IBD mice injected with $200 \mu \mathrm{L}$ of LS-NO $(50 \mu \mathrm{M})$ using ICG filter, $\lambda_{\mathrm{ex}}=710 \mathrm{~nm}$.

\section{Preparation of ROS species}

The NO solution was prepared by adding SNP (Sodium nitroprusside (III) dihydrate) into degassed deionizer water under $\mathrm{N}_{2}$ atmosphere, and then stirred for $40 \mathrm{~min}$ at $25^{\circ} \mathrm{C}$. The $\mathrm{NO}$ concentration of SNP solution was measured based on Griess Method. ${ }^{1} \mathrm{NO}_{2}{ }^{-}$and $\mathrm{ClO}^{-}$solutions $(1 \mathrm{mM})$ were freshly prepared by dissolving $\mathrm{NaNO}_{2}$ and $\mathrm{NaClO}$ into deionized water, respectively. $\mathrm{H}_{2} \mathrm{O}_{2}$ solution $(1 \mathrm{mM})$ was obtained by dilution of commercial $30 \% \mathrm{H}_{2} \mathrm{O}_{2}$ with deionized water. Peroxynitrite $\left(\mathrm{ONOO}^{-}\right)$ 
solution was generated as follows: To the vigorously stirred solution of sodium nitrite $\left(\left(\mathrm{NaNO}_{2}, 0.6\right.\right.$ M) and hydrogen peroxide $\left(\mathrm{H}_{2} \mathrm{O}_{2}, 0.7 \mathrm{M}\right)$, a solution of hydrochloric acid $(\mathrm{HCl}, 0.6 \mathrm{M})$ was added, and then sodium hydroxide $(\mathrm{NaOH}, 1 \mathrm{M})$ was quickly added to make the solution alkaline. The solution was passed through a short column of manganese dioxide to eliminate excess hydrogen peroxide. The concentration of $\mathrm{ONOO}^{-}$was determined by measuring the absorption of the solution at $302 \mathrm{~nm}$ with an extinction coefficient of $1670 \mathrm{M}^{-1} \mathrm{~cm}^{-1}$. Hydroxyl radical $(\bullet \mathrm{OH})(1 \mathrm{mM})$ was generated in situ via Fenton reaction between $\mathrm{FeCl}_{2}$ and $\mathrm{H}_{2} \mathrm{O}_{2}$ quantitively, and $\mathrm{FeCl}_{2}$ concentration represented $\bullet \mathrm{OH}$ concentration. ${ }^{3}$ Singlet oxygen $\left({ }^{1} \mathrm{O}_{2}\right)$ was generated by the reaction between $\mathrm{NaClO}(1 \mathrm{mM})$ and $\mathrm{H}_{2} \mathrm{O}_{2}$ $(1 \mathrm{mM})$.

\section{Spectroscopic measurements}

The UV-vis absorbance and fluorescence emission spectra of LS-NO $(50 \mu \mathrm{M})$ and LS-TZ $(50 \mu \mathrm{M})$ were measured in aqueous solution ( $\mathrm{pH} 5.0$ citrate buffer, containing 1\% Triton X-100) and a mixture of DMF/aqueous solution ( $\mathrm{v} / \mathrm{v}, 1 / 1)$, respectively. The fluorescence response spectra of probe LS-NO in the presence of various concentrations of $\mathrm{NO}$ were measured in a mixture of DMF/aqueous solution (v/v, 1/1). $1 \mathrm{~mL}$ of $20 \mu \mathrm{M}$ LS-NO was mixed with an equal volume of various concentrations of NO solution in $4 \mathrm{~mL}$ tubes. These tubes were then kept in the dark for $1 \mathrm{~h}$ before the measurement of emission spectra. For the selectivity, LS-NO $(50 \mu \mathrm{M})$ were incubated with $100 \mu \mathrm{M} \mathrm{NO}, 1 \mathrm{mM} \mathrm{ONOO}^{-}$, ${ }^{1} \mathrm{O}_{2}, \cdot \mathrm{OH}, \mathrm{H}_{2} \mathrm{O}_{2}, \mathrm{ClO}^{-}$, L-Asp, L-Tyr, L-Arg, L-Glu, GSH, Cys, $\mathrm{S}_{2} \mathrm{O}_{3}{ }^{2-}, \mathrm{S}^{2-}, \mathrm{HSO}_{3}{ }^{-}, \mathrm{Zn}^{2+}, \mathrm{K}^{+}, \mathrm{Fe}^{2+}$, $\mathrm{Ca}^{2+}, \mathrm{Cu}^{+}, \mathrm{NO}^{2-}, \mathrm{SCN}^{-}, \mathrm{Fe}^{3+}, \mathrm{Cu}^{2+}$, and $\mathrm{Mg}^{2+}$ for $1 \mathrm{~h}$, respectively, followed by measurement of fluorescence spectra. Unless stated otherwise, excitation at $650 \mathrm{~nm}$ was used for probe LS-NO. The limit of detection (LOD) was calculated based on the method of $3 \sigma / \mathrm{k}$, where $\sigma$ was the standard deviation of blank measurement, and $\mathrm{k}$ was the slope between the fluorescence intensity versus the NO concentration.

\section{Cell culture and cytotoxicity assay}

RAW 264.7 cells and HCC1299 cells were cultured in high glucose DMEM Medium and RPMI1640 medium, respectively, both containing 10\% fetal bovine serum (FBS) and 1\% antibiotics (penicillin/streptomycin, $100 \mathrm{U} / \mathrm{mL}$ ). The cells were maintained at $37{ }^{\circ} \mathrm{C}$ under a humidified atmosphere with $5 \% \mathrm{CO}_{2}$. The cytotoxicities of LS-NO and LS-TZ were evaluated by CCK-8 assay. Cells were seeded in a white opaque flat-bottom 96-well plate at a cell density of 10,000 cells per well in $100 \mu \mathrm{L}$ growth medium. After $24 \mathrm{~h}$ to allow cell adhesion, the medium was exchanged for $200 \mu \mathrm{L}$ fresh growth medium. Then LS-NO and LS-TZ were added to the cells for final concentrations of 0 to $20 \mu \mathrm{M}$, followed by incubation for 20 hours. After that, the medium was removed, and cells were washed twice with $100 \mu \mathrm{L}$ PBS buffer. Subsequently, $100 \mu \mathrm{L}$ fresh medium and $10 \mu \mathrm{L}$ of CCK-8 was added, followed by incubation for 1 hour. Finally, the absorbance value was recorded at $450 \mathrm{~nm}$ on a Tecan Infinite M Plex microplate reader.

\section{Fluorescence imaging in living cells}

Prior to confocal imaging studies, HCC1299 cells and RAW 264.7 cells were seeded in confocal culture dishes and allowed to attach. After culturing overnight at $37^{\circ} \mathrm{C}$, the old medium was removed and replaced with fresh DMEM or RPMI. For colocalization imaging, LS-NO (5 $\mu \mathrm{M})$ was added and 
the cells were incubated for $1 \mathrm{~h}$, followed by addition of 10 equiv NO for another $1 \mathrm{~h}$. Then the cells were washed twice with PBS and incubated with LysoTracker Green $(500 \mathrm{nM})$ for $30 \mathrm{~min}$. After labeling, cells were washed twice with PBS and incubated with fresh PBS for fluorescence imaging. For exogenous NO imaging, cells were incubated with $5 \mu \mathrm{M} \mathrm{LS-NO}$ for $1 \mathrm{~h}$ at $37^{\circ} \mathrm{C}$. After washing twice with PBS, the cells were incubated with different concentrations of SNP (0-400 $\mu \mathrm{M})$ for $1 \mathrm{~h}$. Finally, the cells were washed twice with PBS and then subjected to fluorescence imaging. For endogenous NO imaging, RAW 264.7 cells were divided into 4 groups. For the first group, cells were incubated normally with no treatment. For the second group, cells were incubated with $5 \mu \mathrm{M}$ LS-NO for $1 \mathrm{~h}$ and then washed with PBS before imaging. For the third group, cells were pretreated with 20 $\mu \mathrm{g} / \mathrm{mL}$ LPS and $5 \mathrm{mg} / \mathrm{mL}$ L-Arg for $12 \mathrm{~h}$, and then incubated with $5 \mu \mathrm{M} \mathrm{LS-NO}$ for $1 \mathrm{~h}$ and washed with PBS before imaging. For the fourth group, cells were pretreated with $20 \mu \mathrm{g} / \mathrm{mL} \mathrm{LPS}, 5 \mathrm{mg} / \mathrm{ml} \mathrm{L}$ Arg, and $10 \mu \mathrm{M}$ L-NNA for $12 \mathrm{~h}$, and then incubated with $5 \mu \mathrm{M} \mathrm{LS-NO}$ for $1 \mathrm{~h}$ and washed with PBS before imaging. For HCC1299 cells, similar experiments were performed. One more experiment, the cells were pretreated with $30 \mu \mathrm{g} / \mathrm{mL}$ hemoglobin $(\mathrm{Hb})$ for $2 \mathrm{~h}$, and then incubated with $5 \mu \mathrm{M} \mathrm{LS-NO}$ for $1 \mathrm{~h}$ and washed with PBS before imaging. Images were analyzed using ImageJ software (NIH).

\section{Fluorescence imaging of the mice}

Female Balb/c mice (6-8 weeks old, 18-20 g) were purchased from Beijing Vital River Laboratory Animal Technology Co., Ltd. All animal experiments were approved by the Ethical Committee of Nankai University and were conducted in accordance with the guidelines for animal experiments. Prior to experiment, the hairs on the chest of Balb/c mice were removed using depilatory cream. The mice were randomly divided into four groups. (a) PBS group: The mice were intravenously injected with $200 \mu \mathrm{L}$ of PBS for $24 \mathrm{~h}$. (b) PBS+probe group: The mice were intravenously injected with $200 \mu \mathrm{L}$ of PBS for $24 \mathrm{~h}$, followed by injection of probe LS-NO $(50 \mu \mathrm{M}, 200 \mu \mathrm{L}$ PBS containing $2 \%$ DMSO). (c) LPS+ probe group: The mice were intravenously injected with $2.5 \mathrm{mg} / \mathrm{kg}$ LPS for $24 \mathrm{~h}$, followed by injection of probe LS-NO (50 $\mu$ M, $200 \mu \mathrm{L}$ PBS containing 2\% DMSO). (d) LPS+L-Arg+probe group: The mice were first intravenously injected with $2.5 \mathrm{mg} / \mathrm{kg}$ LPS and then intraperitoneally injected with $5 \mathrm{mg}$ L-Arg for $24 \mathrm{~h}$, followed by injection of probe LS-NO $(50 \mu \mathrm{M}, 200 \mu \mathrm{L}$ PBS containing $2 \%$ DMSO). Mice were anesthetized with $2.5 \%$ isofluorane in oxygen at selected time points and the whole body NIR fluorescence images (the Cy5.5 or ICG filter was used) were captured using an IVIS Lumina imaging system. At the end point, mice were euthanized and their livers, lungs, hearts, kidneys, spleens, and intestines were immediately collected for ex vivo fluorescence imaging on the IVIS Lumina system. 


\section{Synthesis of probes}<smiles>O=[N+]([O-])c1c([N+](=O)[O-])c(Br)c2nsnc2c1Br</smiles>

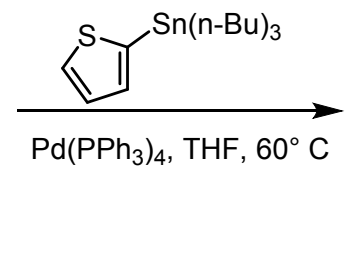<smiles>O=[N+]([O-])c1c(-c2cccs2)c(-c2cccs2)c2nsnc2c1-c1cccs1</smiles><smiles></smiles><smiles>[R]Oc1ccc(B2OC(C)(C)C(C)(C)O2)cc1</smiles>

$\mathrm{Pd}\left(\mathrm{PPh}_{3}\right)_{4}, \mathrm{Tol} / \mathrm{H}_{2} \mathrm{O}, \mathrm{K}_{2} \mathrm{CO}_{3}$, refluxing<smiles>[R]Oc1ccc(-c2ccc(-c3c([N+](=O)[O-])c([N+](=O)[O-])c(-c4ccc(-c5ccc([R])cc5)s4)c4nsnc34)s2)cc1</smiles><smiles>[R]Oc1ccc(-c2ccc(-c3c(-c4ccc(-c5ccc([R20])cc5)s4)nc(-c4ccco4)c([N+](=O)[O-])c3[N+](=O)[O-])s2)cc1</smiles><smiles></smiles>

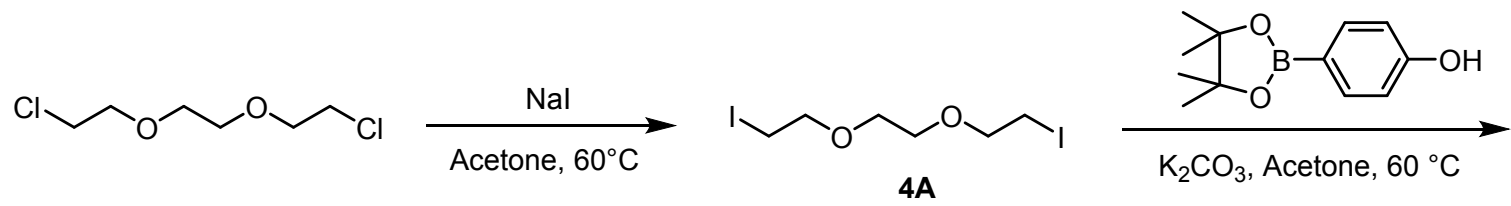<smiles>CC1(C)OB(c2ccc(OCCOCCOCCI)cc2)OC1(C)C</smiles><smiles>CCOC(=O)OC(C)C</smiles><smiles>[R]Oc1ccc(B2OC(C)(C)C(C)(C)O2)cc1</smiles>

The compounds $\mathbf{1}$ and $\mathbf{2}$ were synthesized according to the literature procedures. ${ }^{4}$

Compound 2: ${ }^{1} \mathrm{H}$ NMR (400 MHz, DMSO- $\left.d_{6}\right) \delta 8.06(\mathrm{dd}, J=5.2,1.2 \mathrm{~Hz}, 2 \mathrm{H}), 7.52(\mathrm{dd}, J=3.6,1.2$ $\mathrm{Hz}, 2 \mathrm{H}), 7.32(\mathrm{dd}, J=5.2,3.6 \mathrm{~Hz}, 2 \mathrm{H}) .{ }^{13} \mathrm{C} \mathrm{NMR}\left(100 \mathrm{MHz}, \mathrm{DMSO}-d_{6}\right) \delta 152.0,140.8,132.1,131.2$, 129.3, 128.0, 121.7 .

Synthesis of 3: Compound 2 (1.15 g, $2.95 \mathrm{mmol})$ was dissolved in DMF (100 mL). The solution was heated to $60{ }^{\circ} \mathrm{C}$, one portion of N-bromosuccinimide (NBS, $1.15 \mathrm{~g}, 6.45 \mathrm{mmol}$ ) was added. After $2 \mathrm{~h}$, another portion of NBS $(1.15 \mathrm{~g}, 6.45 \mathrm{mmol})$ was added and monitored by TLC. When the reaction was finished, the mixture was poured into ice water slowly. The precipitates were collected by filtration 
and washed with water and methanol, affording compound 3 as orange powder (1.33 $\mathrm{g}, 81.4 \%$ yield). ${ }^{1} \mathrm{H}$ NMR (400 MHz, DMSO- $\left.d_{6}\right) \delta 7.45(\mathrm{~d}, J=4.0 \mathrm{~Hz}, 2 \mathrm{H}), 7.32(\mathrm{~d}, J=4.0 \mathrm{~Hz}, 2 \mathrm{H}) .{ }^{13} \mathrm{C}$ NMR $(100$ MHz, DMSO- $\left.d_{6}\right) \delta 151.8,140.8,131.8,131.3,130.9,120.9,118.0$.

Synthesis of 4A: A mixture of 1,2-bis(2-chloroethoxy)ethane $(5.0 \mathrm{~g}, 26.7 \mathrm{mmol})$ and NaI (12.0 g, 80.2 $\mathrm{mmol})$ in acetone $(50 \mathrm{~mL})$ was stirred at $60{ }^{\circ} \mathrm{C}$ for $72 \mathrm{~h}$ under $\mathrm{N}_{2}$ atmosphere. After filtration of the generated sodium chloride, the acetone was removed under reduced pressure. The residue thus obtained was dissolved in $\mathrm{CH}_{2} \mathrm{Cl}_{2}(200 \mathrm{~mL})$. Then the solution was washed with brine, dried over anhydrous sodium sulfate, filtered, and concentrated. The crude product was purified by flash column chromatography over silica gel using petroleum ether/ethyl acetate (10/1) as the eluent, affording a colorless oil ( $8.3 \mathrm{~g}, 84.0 \%$ yield). ${ }^{1} \mathrm{H}$ NMR $\left(400 \mathrm{MHz}, \mathrm{CDCl}_{3}\right) \delta 3.75$ (t, $\left.J=6.8 \mathrm{~Hz}, 4 \mathrm{H}\right), 3.65(\mathrm{~s}, 4 \mathrm{H})$, $3.25(\mathrm{t}, J=6.8 \mathrm{~Hz}, 4 \mathrm{H}) .{ }^{13} \mathrm{C} \mathrm{NMR}\left(100 \mathrm{MHz}, \mathrm{CDCl}_{3}\right) \delta 72.2,70.4,3.1$.

Synthesis of 4B: A mixture of compound 4A $(5.0 \mathrm{~g}, 13.6 \mathrm{mmol})$, 4-Hydroxyphenylboronic acid pinacol ester $(1.0 \mathrm{~g}, 4.5 \mathrm{mmol})$, and $\mathrm{K}_{2} \mathrm{CO}_{3}(1.9 \mathrm{~g}, 13.7 \mathrm{mmol})$ in acetone $(30 \mathrm{~mL})$ was stirred at $60{ }^{\circ} \mathrm{C}$ for $48 \mathrm{~h}$ under $\mathrm{N}_{2}$ atmosphere. The acetone was removed under reduced pressure, and the residue thus obtained was dissolved in $\mathrm{CH}_{2} \mathrm{Cl}_{2}(200 \mathrm{~mL})$. Then the solution was washed with brine, dried over anhydrous sodium sulfate, filtered, and concentrated. The crude product was purified by flash column chromatography over silica gel using DCM/MeOH (100/1) as the eluent, affording a colorless oil (1.5 g, $72.2 \%$ yield). ${ }^{1} \mathrm{H}$ NMR (400 MHz, $\left.\mathrm{CDCl}_{3}\right) \delta 7.73(\mathrm{~d}, J=8.8 \mathrm{~Hz}, 2 \mathrm{H}), 6.90(\mathrm{~d}, J=8.8 \mathrm{~Hz}, 2 \mathrm{H}), 4.15$ $(\mathrm{t}, J=5.2 \mathrm{~Hz}, 2 \mathrm{H}), 3.86(\mathrm{t}, J=4.8 \mathrm{~Hz}, 2 \mathrm{H}), 3.75(\mathrm{t}, J=6.8 \mathrm{~Hz}, 2 \mathrm{H}), 3.72(\mathrm{t}, J=3.2 \mathrm{~Hz}, 2 \mathrm{H}), 3.68(\mathrm{t}$, $J=2.8 \mathrm{~Hz}, 2 \mathrm{H}), 3.24(\mathrm{t}, J=7.2 \mathrm{~Hz}, 2 \mathrm{H}), 1.32(\mathrm{~s}, 12 \mathrm{H}) .{ }^{13} \mathrm{C} \mathrm{NMR}\left(100 \mathrm{MHz}, \mathrm{CDCl}_{3}\right) \delta 161.5,136.7$, $114.1,83.7,72.2,71.0,70.4,70.0,67.4,25.0,3.1$.

Synthesis of 4: A mixture of compound 4B (1.15 g, $2.5 \mathrm{mmol})$, morpholine (0.65 g, $7.5 \mathrm{mmol})$, and $\mathrm{K}_{2} \mathrm{CO}_{3}(0.52 \mathrm{~g}, 3.8 \mathrm{mmol})$ in acetone $(30 \mathrm{~mL})$ was stirred at $60{ }^{\circ} \mathrm{C}$ for $48 \mathrm{~h}$ under $\mathrm{N}_{2}$ atmosphere. The acetone was removed under reduced pressure, and the residue thus obtained was dissolved in $\mathrm{CH}_{2} \mathrm{Cl}_{2}$ $(200 \mathrm{~mL})$. Then the solution was washed with brine, dried over anhydrous sodium sulfate, filtered, and concentrated. The crude product was purified by flash column chromatography over silica gel using $\mathrm{DCM} / \mathrm{MeOH}(20 / 1)$ as the eluent, affording a colorless oil $\left(1.0 \mathrm{~g}, 97.4 \%\right.$ yield). ${ }^{1} \mathrm{H} \mathrm{NMR}(400 \mathrm{MHz}$, $\left.\mathrm{CDCl}_{3}\right) \delta 7.71(\mathrm{~d}, J=8.8 \mathrm{~Hz}, 2 \mathrm{H}), 6.87(\mathrm{~d}, J=8.8 \mathrm{~Hz}, 2 \mathrm{H}), 4.12(\mathrm{t}, J=4.8 \mathrm{~Hz}, 2 \mathrm{H}), 3.82(\mathrm{t}, J=4.8$ $\mathrm{Hz}, 2 \mathrm{H}), 3.70-3.66(\mathrm{~m}, 6 \mathrm{H}), 3.62-3.59(\mathrm{~m}, 4 \mathrm{H}), 2.55(\mathrm{t}, J=6.0 \mathrm{~Hz}, 2 \mathrm{H}), 2.46(\mathrm{t}, J=4.8 \mathrm{~Hz}, 4 \mathrm{H}), 1.30$ (s, 12H). ${ }^{13} \mathrm{C} \mathrm{NMR}\left(100 \mathrm{MHz}, \mathrm{CDCl}_{3}\right) \delta 161.4,136.6,114.0,83.6,71.0,70.5,69.7,68.6,67.3,66.9$, $58.3,54.1,25.0$.

Synthesis of 5: Compound 3 (0.5 g, $0.9 \mathrm{mmol})$, compound 4 (0.96 g, $2.3 \mathrm{mmol}), \mathrm{K}_{2} \mathrm{CO}_{3}(0.5 \mathrm{~g}, 3.6$ $\mathrm{mmol})$, and $\mathrm{Pd}\left(\mathrm{PPh}_{3}\right)_{4}(104 \mathrm{mg}, 0.09 \mathrm{mmol})$ were dissolved in $30 \mathrm{~mL}$ toluene $/ \mathrm{H}_{2} \mathrm{O}(2 / 1)$ mixture under $\mathrm{N}_{2}$ atmosphere. The resulting solution was heated to reflux for $24 \mathrm{~h}$. After cooling down, the mixture was extracted with DCM. The organic layer was washed with brine, dried over anhydrous sodium sulfate, filtered, and concentrated. The crude product was purified by flash column chromatography over silica gel using DCM/MeOH (15/1) as the eluent, affording compound 5 as a purple solid $(0.79$ g, 88.9\% yield). ${ }^{1} \mathrm{H}$ NMR (400 MHz, $\left.\mathrm{CDCl}_{3}\right) \delta 7.61(\mathrm{~d}, J=8.8 \mathrm{~Hz}, 4 \mathrm{H}), 7.50(\mathrm{~d}, J=4.4 \mathrm{~Hz}, 2 \mathrm{H}), 7.30$ $(\mathrm{d}, J=4.0 \mathrm{~Hz}, 2 \mathrm{H}), 6.97(\mathrm{~d}, J=8.8 \mathrm{~Hz}, 4 \mathrm{H}), 4.18(\mathrm{t}, J=4.8 \mathrm{~Hz}, 4 \mathrm{H}), 3.88$ (t, $J=4.8 \mathrm{~Hz}, 4 \mathrm{H}), 3.75-$ 
$3.70(\mathrm{~m}, 12 \mathrm{H}), 3.67-3.63(\mathrm{~m}, 8 \mathrm{H}), 2.60(\mathrm{t}, J=6.0 \mathrm{~Hz}, 4 \mathrm{H}), 2.51(\mathrm{t}, J=4.8 \mathrm{~Hz}, 8 \mathrm{H}) .{ }^{13} \mathrm{C}$ NMR $(100$ $\left.\mathrm{MHz}, \mathrm{CDCl}_{3}\right) \delta 160.0,152.3,151.2,132.4,130.2,128.0,127.8,126.4,123.3,120.8,115.4,71.1,70.6$, $69.9,68.8,67.8,67.0,58.5,54.2$.

Synthesis of probe LS-NO: To a mixture solution of compound $5(0.3 \mathrm{~g}, 0.33 \mathrm{mmol})$ in $15 \mathrm{~mL}$ $\mathrm{MeOH} / \mathrm{THF}(1 / 2)$, palladium on carbon $(5 \%, 0.2 \mathrm{~g})$ was added. The reaction flask was evacuated and back-filled with hydrogen (three times), and the resulting mixture was stirred at $50{ }^{\circ} \mathrm{C}$ under a hydrogen balloon for $48 \mathrm{~h}$. The catalyst was filtered off and the filtrate was concentrated under vacuum. The crude product was purified by flash column chromatography over silica gel using DCM/MeOH (10/1), affording an orange solid (0.24 g, 78.8\% yield). ${ }^{1} \mathrm{H}$ NMR $\left(400 \mathrm{MHz}, \mathrm{DMSO}-d_{6}\right) \delta 7.64(\mathrm{~d}, J=$ $8.4 \mathrm{~Hz}, 4 \mathrm{H}), 7.48(\mathrm{~d}, J=4.0 \mathrm{~Hz}, 2 \mathrm{H}), 7.30(\mathrm{~d}, J=3.6 \mathrm{~Hz}, 2 \mathrm{H}), 7.02(\mathrm{~d}, J=8.4 \mathrm{~Hz}, 4 \mathrm{H}), 5.95(\mathrm{~s}, 4 \mathrm{H})$, $4.14(\mathrm{t}, J=4.8 \mathrm{~Hz}, 4 \mathrm{H}), 3.76(\mathrm{t}, J=4.8 \mathrm{~Hz}, 4 \mathrm{H}), 3.61-3.51(\mathrm{~m}, 20 \mathrm{H}), 2.45(\mathrm{t}, J=6.0 \mathrm{~Hz}, 4 \mathrm{H}), 2.38(\mathrm{t}$, $J=4.8 \mathrm{~Hz}, 8 \mathrm{H}) .{ }^{13} \mathrm{C}$ NMR $\left(100 \mathrm{MHz}, \mathrm{DMSO}-d_{6}\right) \delta 158.1,150.0,143.5,140.1,134.4,129.5,126.6$, $122.4,115.1,101.6,69.9,69.6,68.9,68.1,67.3,66.2,57.6,53.7$.

Synthesis of LS-TZ: To a $25 \mathrm{~mL}$ three-necked flask containing $4 \mathrm{~mL}$ THF/acetic acid (1/1) under $\mathrm{N}_{2}$ atmosphere, probe LS-NO (20 mg, $0.022 \mathrm{mmol}$ ) was quickly added. Sodium nitrite $(4.5 \mathrm{mg}, 0.066$ mmol) dissolved in $200 \mu \mathrm{L}$ degassed water (sparging with nitrogen for 10 minutes) was added dropwise over two hours. The reaction mixture was stirred at room temperature overnight, and then poured into a saturated $\mathrm{NaHCO}_{3}$ solution $(20 \mathrm{~mL})$. This mixture was extracted with DCM $(3 \times 10 \mathrm{~mL})$, dried over anhydrous sodium sulfate, filtered, and concentrated. The crude product was purified by flash column chromatography over silica gel using DCM/MeOH (10/1) as the eluent, affording a blue solid (13.7 mg, 66.8\% yield). ${ }^{1} \mathrm{H}$ NMR (400 MHz, DMSO- $\left.d_{6}\right) \delta 8.76(\mathrm{~d}, J=4.0 \mathrm{~Hz}, 2 \mathrm{H}), 7.74(\mathrm{~d}, J=$ $8.4 \mathrm{~Hz}, 4 \mathrm{H}), 7.62(\mathrm{~d}, J=4.0 \mathrm{~Hz}, 2 \mathrm{H}), 7.05(\mathrm{~d}, J=8.4 \mathrm{~Hz}, 4 \mathrm{H}), 4.16(\mathrm{t}, J=4.8 \mathrm{~Hz}, 4 \mathrm{H}), 3.78(\mathrm{t}, J=4.4$ $\mathrm{Hz}, 4 \mathrm{H}), 3.63-3.55(\mathrm{~m}, 20 \mathrm{H}), 2.65(\mathrm{t}, J=6.0 \mathrm{~Hz}, 4 \mathrm{H}), 2.58(\mathrm{t}, J=4.8 \mathrm{~Hz}, 8 \mathrm{H}) .{ }^{13} \mathrm{C}$ NMR $(100 \mathrm{MHz}$, DMSO- $\left.d_{6}\right) \delta 158.4,149.0,145.8,135.3,131.3,129.6,126.7,126.6,123.2,115.2,108.1,69.9,69.7$, $68.9,67.4,67.2,65.5,57.1,53.2$. 


\section{9. ${ }^{1} \mathrm{H}$ NMR and ${ }^{13} \mathrm{C}$ NMR spectra}
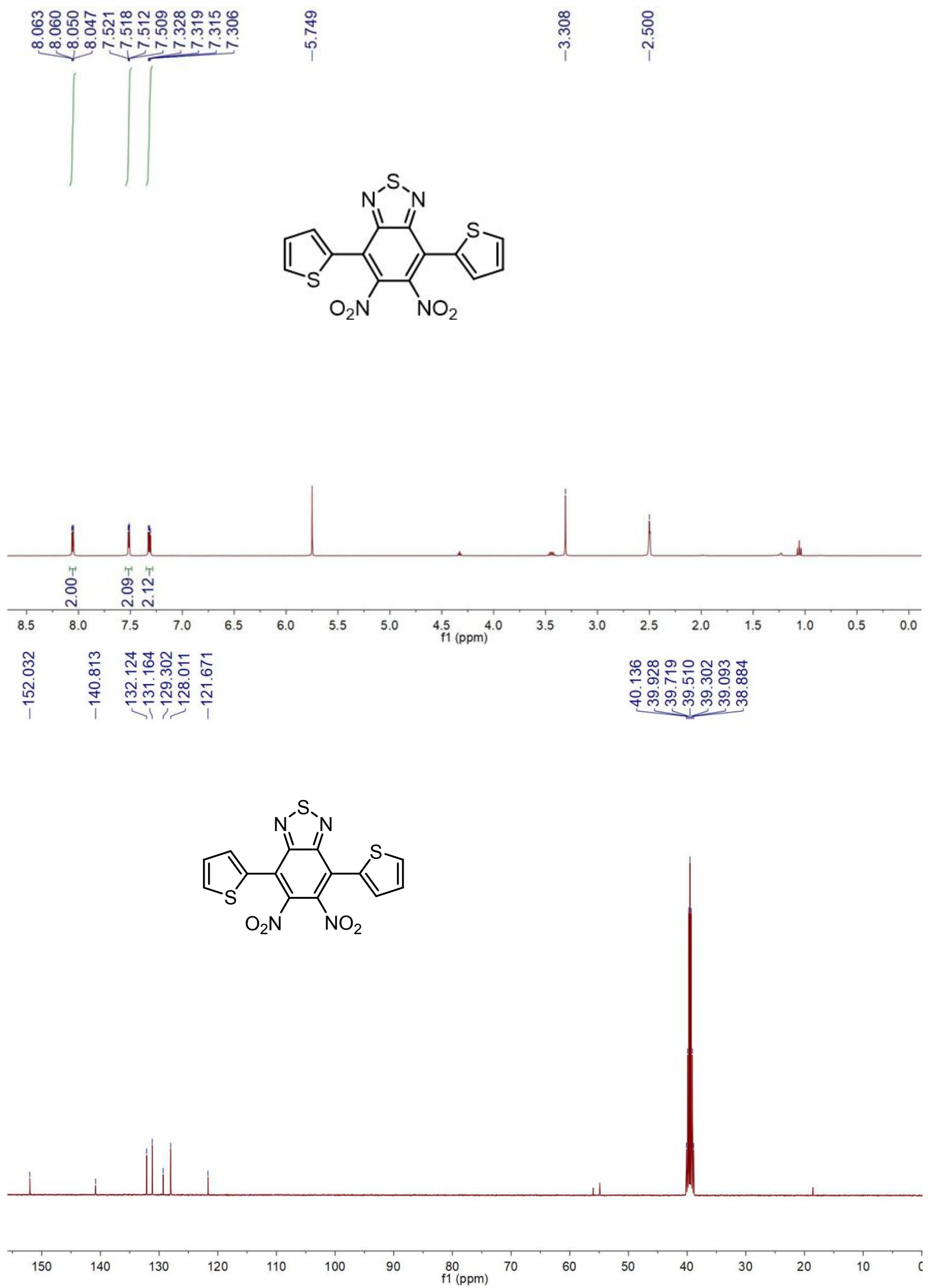

S-10 


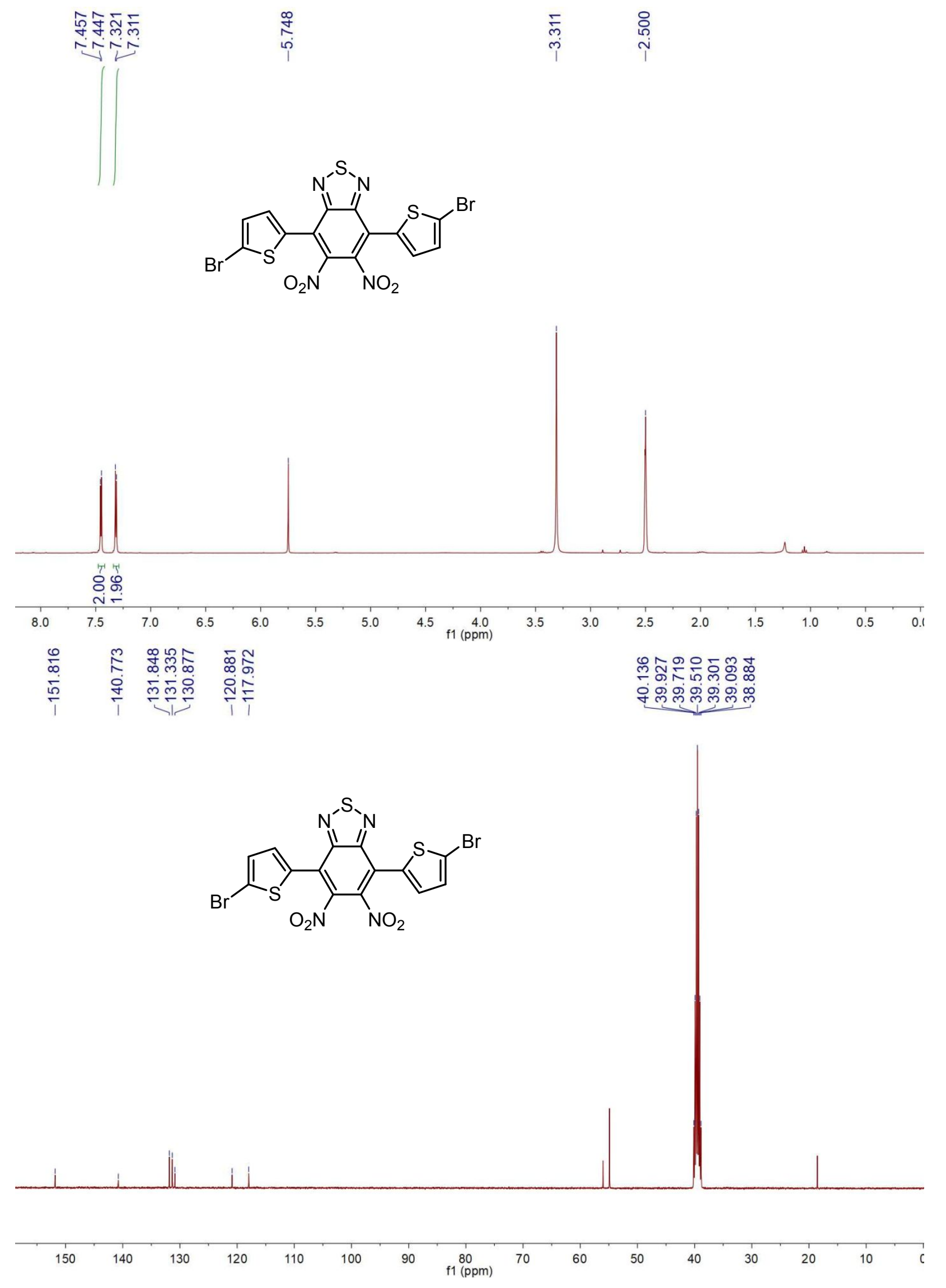


ํํํ

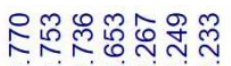

लंखुलालुल

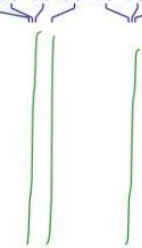

NO

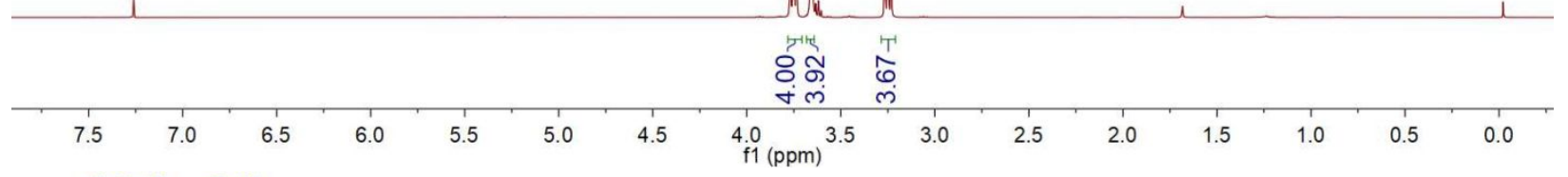

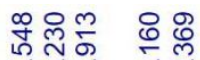

तing

$\stackrel{m}{\stackrel{m}{\infty}}$<smiles>ICCOCCOCCI</smiles>

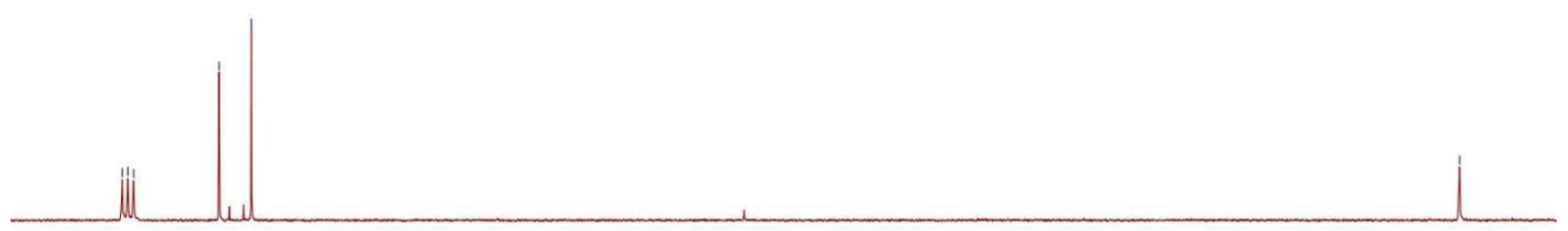

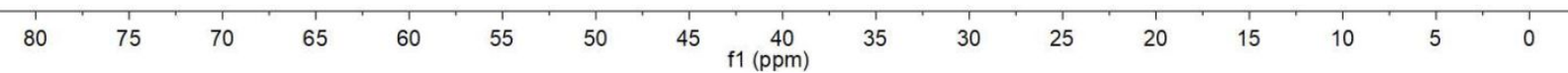




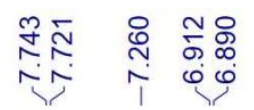

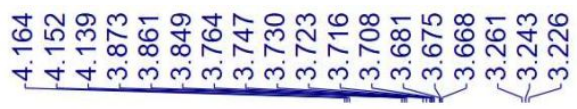

$\int$
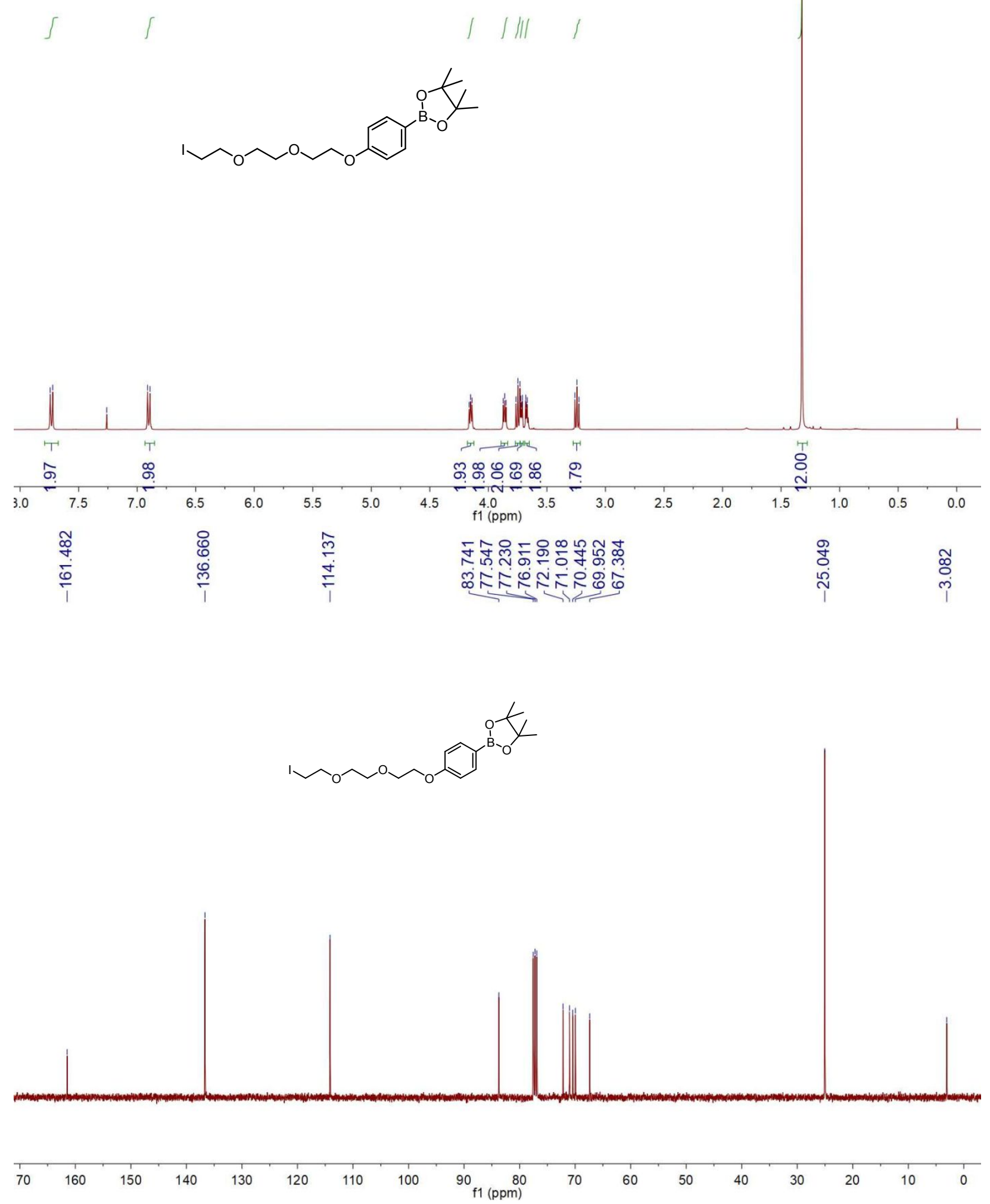

S-13 


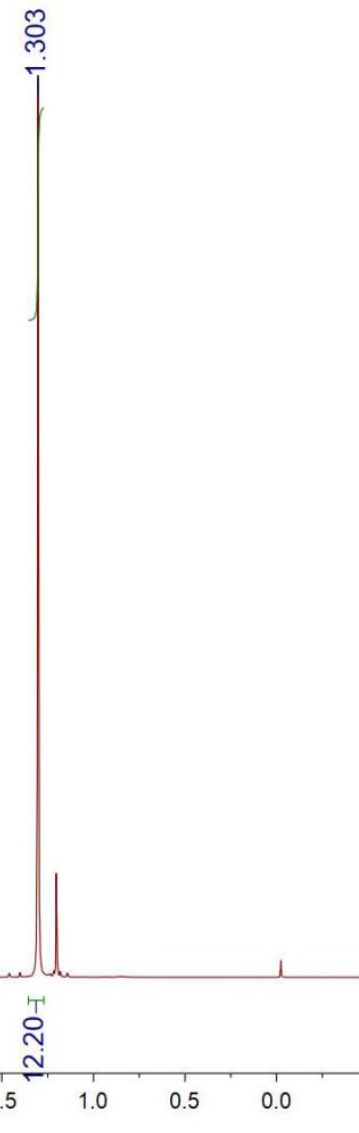

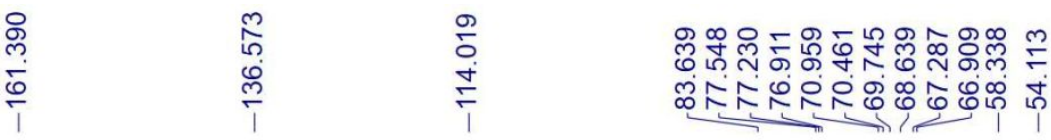
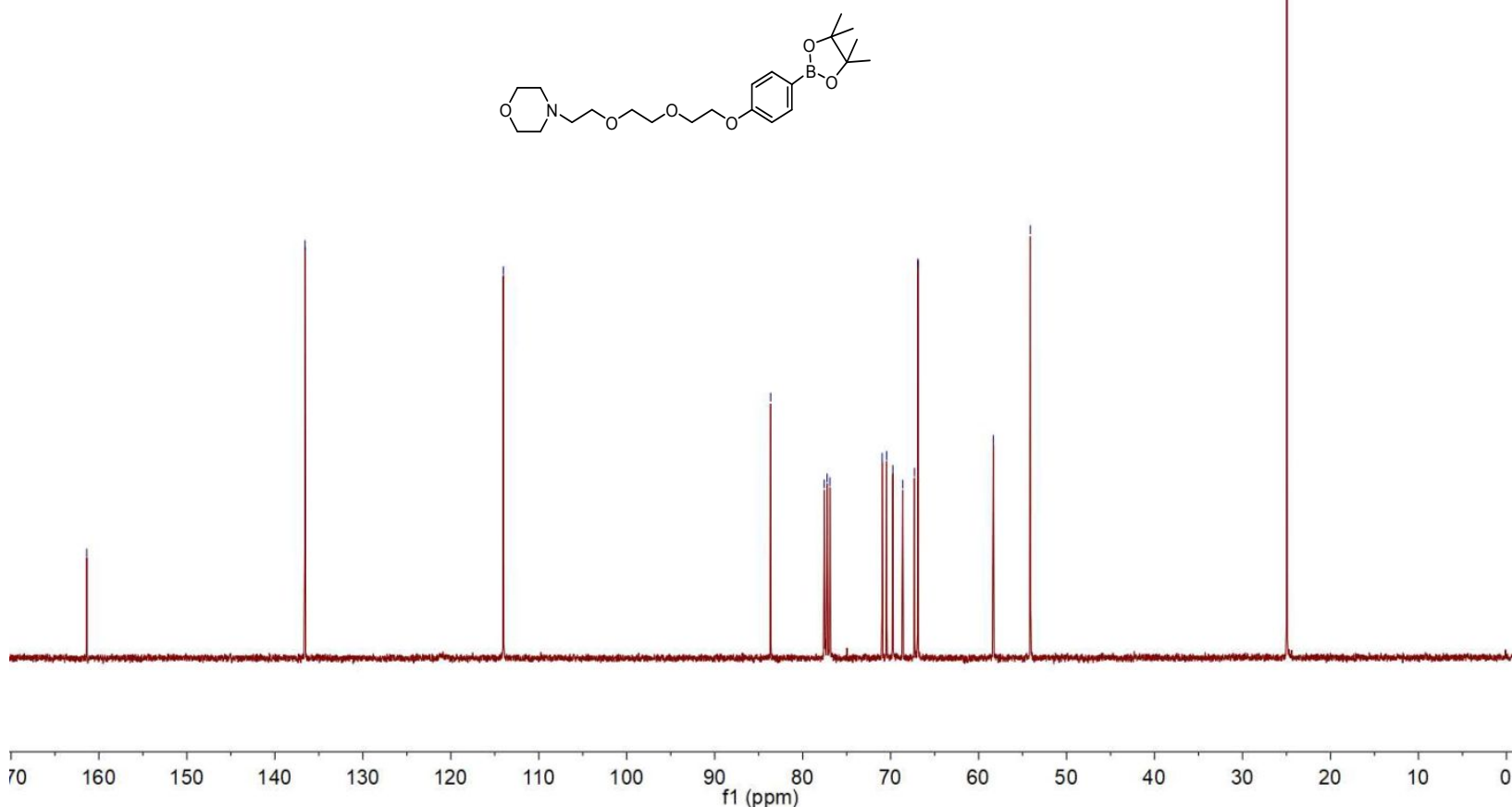


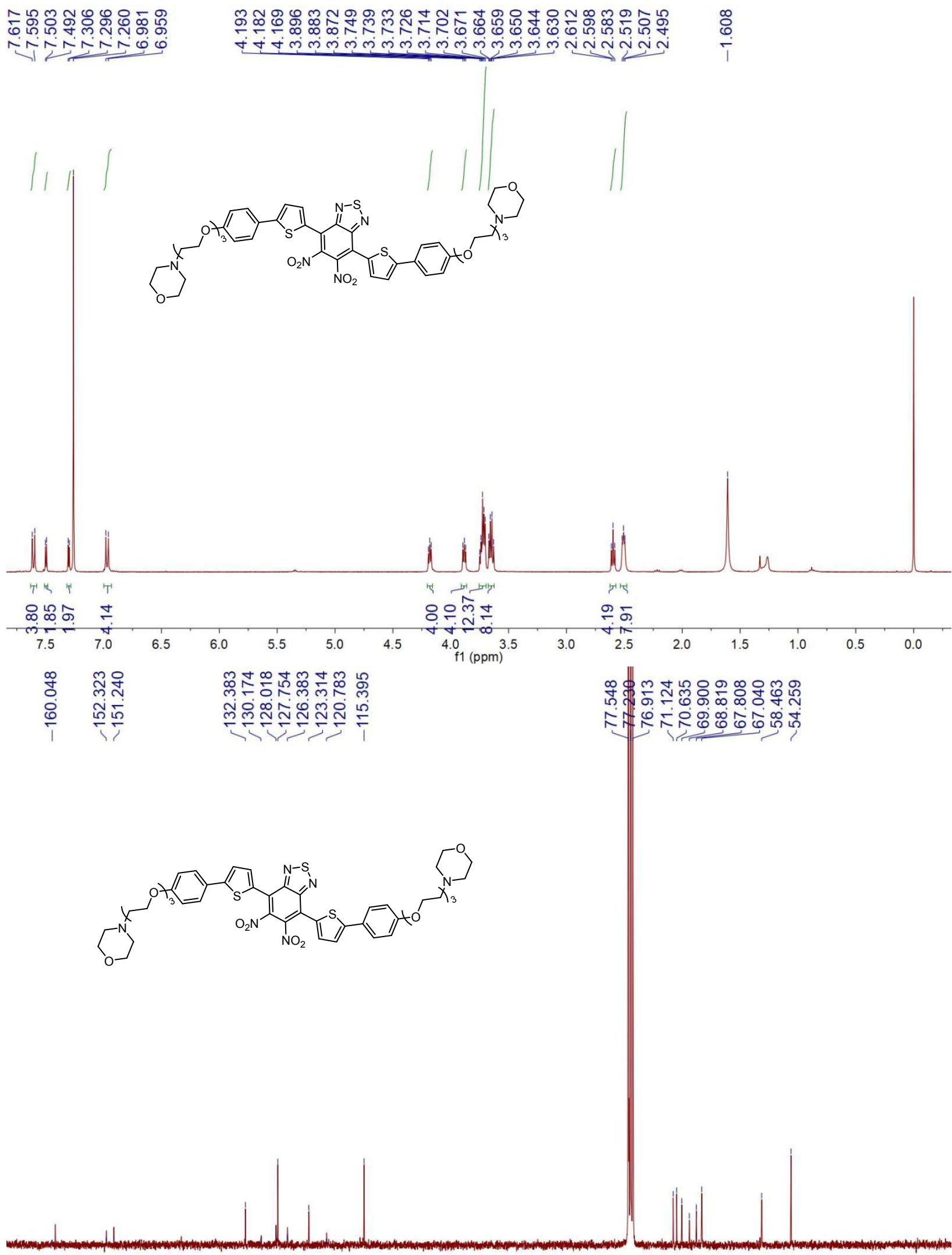

$\begin{array}{lllllllllllllllllllllllllll}165 & 160 & 155 & 150 & 145 & 140 & 135 & 130 & 125 & 120 & 115 & 110 & 105 & \begin{array}{c}100 \\ \mathrm{f} 1(\mathrm{ppm})\end{array} & 95 & 90 & 85 & 80 & 75 & 70 & 65 & 60 & 55 & 50 & 45 & 40 & 35\end{array}$ 


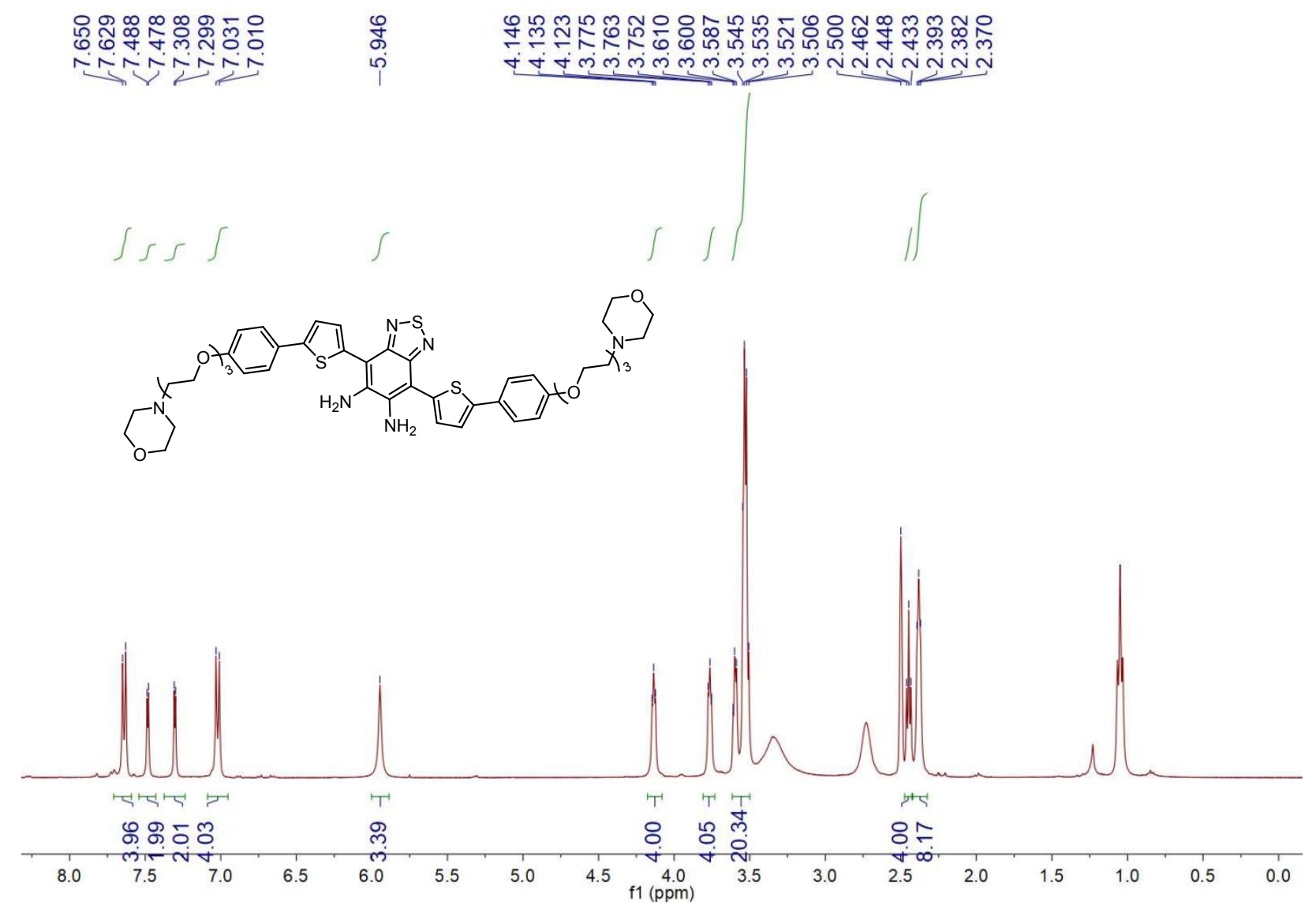



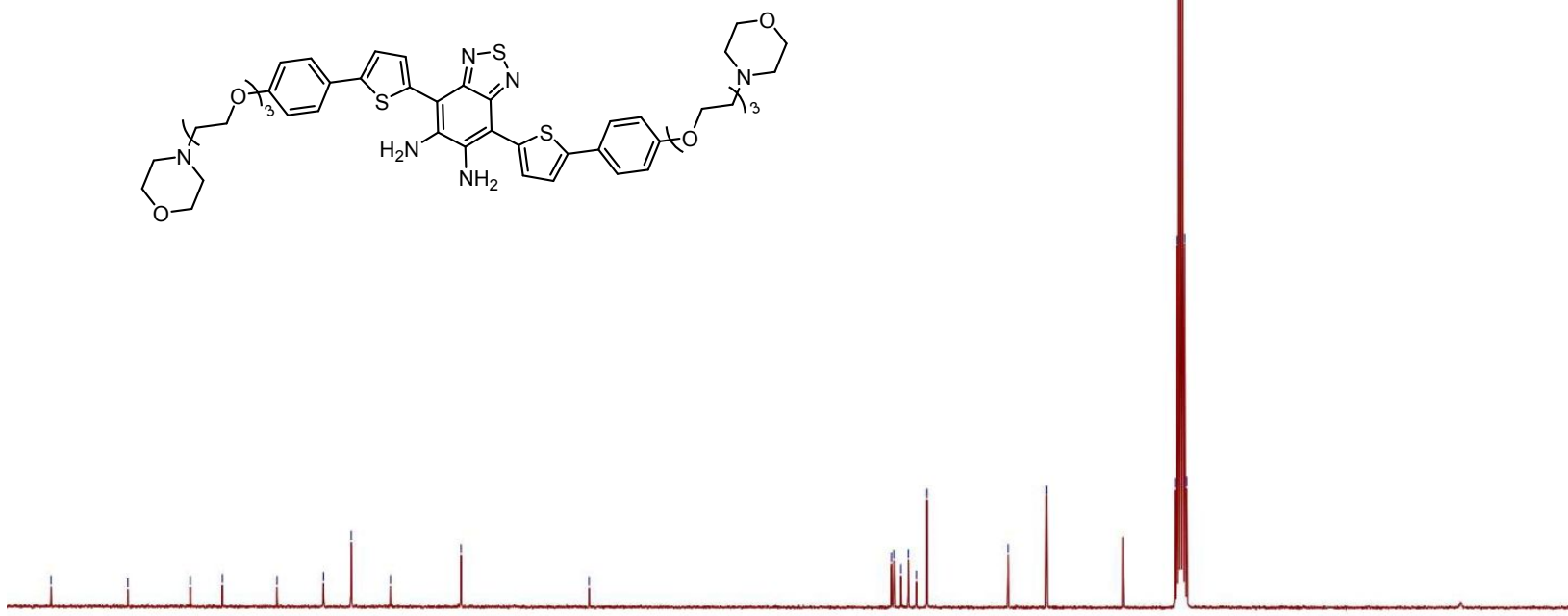

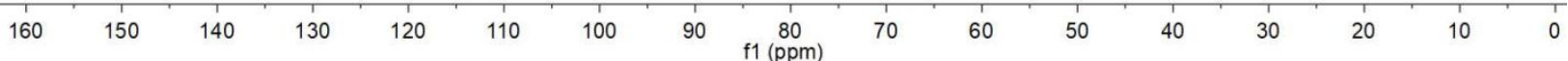



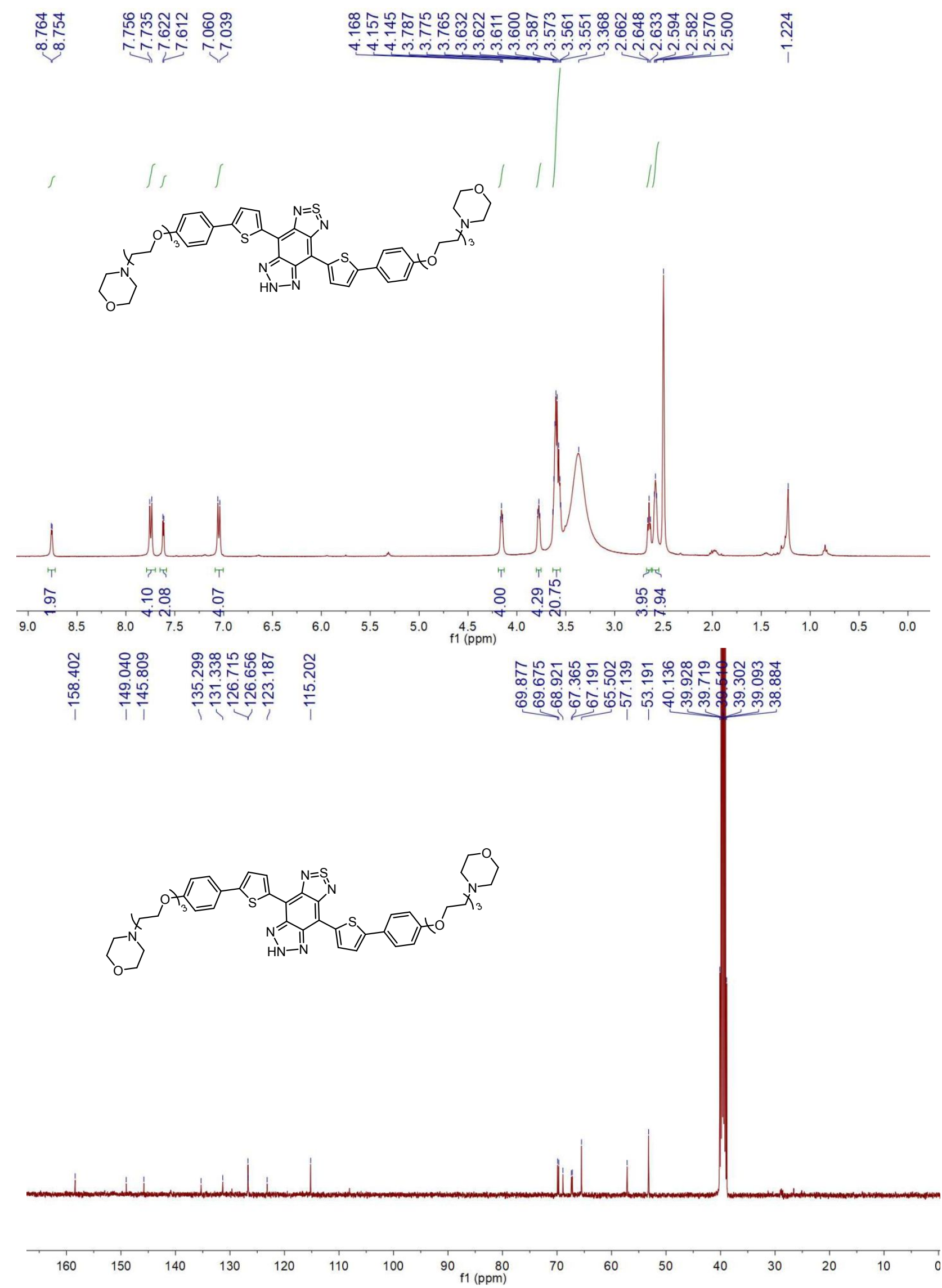


\section{References}

(1) Hunter, R. A.; Storm, W. L.; Coneski, P. N.; Schoenfisch, M. H. Anal. Chem. 2013, 85, 1957-1963.

(2) Peng, T.; Wong, N. K.; Chen, X.; Chan, Y. K.; Sun, Z.; Hu, J. J.; Shen, J.; El-Nezami, H.; Yang, D. J. Am. Chem. Soc. 2014, 136, 11728-11734.

(3) Li, X.; Tao, R. R.; Hong, L. J.; Cheng, J.; Jiang, Q.; Lu, Y. M.; Liao, M. H.; Ye, W. F.; Lu, N. N.; Han, F.; Hu, Y. Z.; Hu, Y. H. J. Am. Chem. Soc. 2015, 137, 12296-12303.

(4) Teng, L.; Song, G.; Liu, Y.; Han, X.; Li, Z.; Wang, Y.; Huan, S.; Zhang, X. B.; Tan, W. J. Am. Chem. Soc. 2019, 141, 13572-13581. 